\title{
India's Export Potential and Competitiveness with UAE: An Exploratory Study
}

\author{
Syed Mohd Shahzeb ${ }^{1 *}$, Himanshu Khushwaha ${ }^{2}$, Tariq Masood ${ }^{3}$ \\ ${ }^{1}$ Ph.D. Scholar, Aligarh Muslim University, Aligarh, India \\ ${ }^{2}$ Consultant, Ministry of Commerce, India \\ ${ }^{3}$ Assistant Professor, Dept. of West Asian \&North African Studies Aligarh Muslim University, Aligarh, India
}

DOI: $10.36348 /$ sjef.2021.v05i01.002

| Received: 13.12.2020 | Accepted: 24.12.2020 | Published: 14.01.2021

*Corresponding author: Syed Mohd Shahzeb

\section{Abstract}

The study is an attempt to investigate the India's bilateral trade profile and export potential of India with United Arab Emirates (UAE) over the period 2001-2018. In addition to exploring the bilateral trade with UAE, it also throws light on how India has performed globally during the same period. In order to analyze India's export intensity, complementarity, diversification \& specialization we resorted to trade indices and Finally, Revealed Comparative Advantage Index (RCA) is calculated to find out what are the lines of specialization that India has in its anvil. Index of competitiveness is calculated both at the global and bilateral level i.e. RCA with world and Bilateral Revealed Comparative Advantage (BRCA) with UAE. It is found that, though, India is second largest supplier to UAE in Merchandise trade, still a major proportion of export revenue is coming from very few lines. Precious stones and Jewellery items accounts for around $30 \%$ of exports earning. Our calculations reveal that there are 228 products in which India has bilateral revealed comparative advantage with UAE, while globally it has revealed comparative advantage in 558 products. Thus, there exists a gap of around 377 products, which India can tap for additional US \$ 6.42 billion of UAE demand where India supplies only US $\$ 1.21$ billion as of 2018 .

Keywords: Revealed Comparative Advantage (RCA), Bilateral Revealed Comparative Advantage (BRCA), Trade Intensity Index (TII), Trade Complementarity Index (TCI), Herfindhal Hirschman Index (HHI).

Copyright (C) 2021 The Author(s): This is an open-access article distributed under the terms of the Creative Commons Attribution 4.0 International License (CC BY-NC 4.0) which permits unrestricted use, distribution, and reproduction in any medium for non-commercial use provided the original author and source are credited.

\section{INTRODUCTION}

Over the year's International trade has become an important factor, or more importantly, a medium in raising living standards across the globe. This holds true, given the fact that International trade explains the major proportion of total economic activity for countries around the world. Trade allow countries to make use of abundant raw material, comparative advantage theory states that countries should focus more on products where they have low opportunity cost, thus leading to greater efficiency due to specialization and economies of scale. It provides consumer with a wider and greater choice to make. It also improves, though not that smooth, transfer and flow of technology from developed to developing countries. Starting with early 1990's India adopted profree trade external sector policies by reducing barriers and tariff reductions. These policies have had large impact on both the volume and composition of trade [1]. Share of merchandise trade in GDP was around 30 percent in 2018-19 and if we consider services trade it goes above 40 percent.
Trade ties between India and UAE is historic and is further corroborated by strong cultural linkages between the two countries. Commodities that were prominently exchanged during the barter trade system includes garments and spices from India \& dates and pearls from UAE. In the last two decades, India's trade relationship with the UAE deepened further, such that as per India's official estimates, during 2017-18, UAE was the second largest destination for merchandise exports from India, valued US \$ 28.14 billion with a total share of $9.27 \%$ of India's total exports [2] and India imported merchandise goods worth US \$ 21.73 billion from UAE making UAE the fourth largest supplier to India in 2017-18 [2].

One of the credible reasons for a strong and sustained trade relation was the strategic geographical location of the two countries. This was maintained and supported by straight and uninterrupted sea route connectivity leading to a smooth flow of goods without imposing much cost to the traders. However, the major reasons behind a sudden and upwards push to bilateral 
trade came with further political recognition between the two countries which started with the establishment of the UAE Embassy in national capital in 1972. In 1973, the Emirati consulate was established in Mumbai, together with the Indian Embassy in Abu Dhabi and the Indian Consulate in Dubai [3].

There are only few attempts in the past to understand India-UAE bilateral trade [4-8] are few notable exceptions. According to [4] only five sectors accounts for majority of India's Exports to UAE (Iron \& steel, Mineral fuels, oils, distillation products, etc., Cereals, Electrical \& Electronic equipment; and Copper and articles thereof.). These products explain around $85 \%$ of India's export earnings from UAE. Similarly, India's import from UAE is mainly of Mineral Fuels etc, Ores, Slag, Pearls, Precious Stones, Inorganic chemicals, and Organic chemicals. Furthermore, UAE was followed by Saudi Arabia. Moreover, it was found that trade Intensity was more than one for UAE, Saudi Arabia, Iran, Kuwait and Oman. With rest of the countries in the region, trade was fluctuating in nature. [5], found that when it comes to trade with the Persian Gulf Countries trade intensity was high with the UAE, such that it accounts for the maximum trade engagement of India's with the Persian Gulf region [6] in their study they found that India's trade intensity both export and import never went below unity that implies the both countries have good trade partnership in comparison with global trade [7] carried out RCA analysis at HS 2-digit level and found that India holds comparative advantage in a number of commodities while UAE holds strong comparative advantage especially in mineral fuels. According to [7], overall results show that keeping in mind the large number of expatriates in UAE, bilateral trade has been increasing and economic integration is expected to have a positive impact on trade variables of both the regions. During 2007 to 2016, trade between India and UAE was growing at a comfortable rate. However, in recent years, India's trade intensity in both export and import never went below unity, which implies that both countries have good trade partnership in comparison with global trade. [8] carried out RCA analysis starting from Standard International Trade Classification (SITC) two-digit going to SITC four-digit level of analysis in respect of India and UAE and found out that China is more significant in the world market as well as in the bilateral market. However, there is a wide possibility of intra-industry trade between India and China in chemicals and compounds, transport and related materials and products, electrical, mechanical, machineries and parts of machineries and accessories, as well as food-based products like oil.

There are only few past studies on bilateral trade profile and have been done at either two digit or at four-digit level. The present study tries to fill this gap by looking at India's competitiveness with UAE at a more disaggregated level. The main objective is to come up with tariff lines [9] that India can propose to UAE to expand its presence in UAE given the fact that India is competitive in these tariff lines at global level.

The present study is an attempt to come up with the potential tariff lines at HS 6 digit which India can further into the UAE markets to increase its share in UAE's total import demand. The study has following specific objectives:

- To analyze long run trends in bilateral trade with UAE in order to see where UAE stands as a trade partner to India.

- To analyze India's trade intensity and trade complementarity and trade diversification with UAE.

- To find out tariff lines in which India have comparative advantage globally and comparative advantage with UAE.

- To come up with the list of products in which India has revealed comparative advantage (RCA) with the World but unable to export it to UAE.

The rest of the paper is organized as follows: next section provides data and methodology, used in the analysis. Third Section explains the brief trade profile of India-UAE. Fourth, discusses the results of various trade indices calculated for understanding India export potential. The last section concludes the findings and suggests policy implications.

\section{THE DATA AND METHODOLOGY}

Considering above mentioned objectives, we compiled data from three sources; UN-Comtrade [10]. World Integrated Trade Solution (WITS) and ITC Trade-Map at HS (Harmonized System) at six-digit level for the period 2001 to 2018. In order to find existing trade potential of India with UAE, the analysis resorted to widely used Trade Indices. This includes Trade Intensity Index (TTI), Trade Complementarity Index (TCI), Hirschman Herfindahl Product Index (HHI), Revealed Comparative Advantage Index (RCA) and Bilateral Revealed Comparative Advantage Index (BRCA). Competitiveness of a product with both RCA \& BRCA is checked, only those products are considered competitive in which India has RCA with the world and BRCA with UAE for the years 2001, 2005, 2010, 2015, 2017 \& 2018. The main reason behind discrete time period with long gap is that Comparative Advantage index is a value driven index that can be easily influenced by sharp movement in prices and hence instability can make it inexplicable.

\section{Trade Intensity Index}

The trade intensity index (TTI) is used to determine whether the value of trade between two countries is greater or smaller than would be expected on the basis of their importance in world trade. It is defined as the share of one country's exports going to a partner divided by the share of world exports going to the partner [11] it is calculated as: 


$$
\mathbf{T}_{\mathrm{ij}}={ }^{\left(\mathbf{X}_{\mathrm{ij}} / \mathbf{X}_{\mathrm{it}}\right) /} /\left(\mathbf{X}_{\mathrm{wj}} / \mathbf{X}_{\mathrm{wt}}\right)
$$

Where Xij and Xwj are the values of country i's exports and of world exports to country $j$ and where Xit and Xwt are country i's total exports and total world exports respectively. An index of more (less) than one indicates a bilateral trade flow that is larger (smaller) than expected, given the partner country's importance in world trade [11].

\section{The Trade Complementarity Index}

The trade complementarity (TCI) index can provide useful information on prospects for intraregional trade as it shows how well the structures of a country's imports and exports match. In other words, Trade complementarity index (TCI) shows how the India's export baskets match the UAE import demand. This is the useful index for knowing the opportunities of export of one country in the other countries import baskets. Here also, we will be trying to find out India's export, supply match with UAE's import demand; and if the complementarity exists, if there are opportunities for India's exports to UAE. If there is mismatch, it implies absence of complementarity and there would be low opportunities of India's exports to UAE. TCI between countries $\mathrm{k}$ and $\mathrm{j}$ is defined as [11].

$$
\operatorname{TCI}_{\mathrm{ij}}=100\left(1-\operatorname{sum}\left(\left|\mathbf{m}_{\mathrm{ik}}-\mathrm{x}_{\mathrm{ij}}\right| / 2\right)\right)
$$

Where $x i j$ is the share of good $i$ in global exports of country $\mathrm{j}$ and mik is the share of good $\mathrm{i}$ in all imports of country $k$. The index is zero when no goods are exported by one country or imported by the other and 100 when the export and import shares exactly match.

\section{Hirschman herfindahl index}

This index is a measure of the degree to which production in a market is either concentrated or dispersed. It is calculated by squaring the market share of each producer in the market and then comparing the sum to a scale. It is the sum of squared shares of each product in total export. A country with a perfectly diversified export portfolio will have an index close to zero, whereas a country which exports only one product will have a value of 1 (least diversified) [11].

\section{Revealed comparative advantage (RCA)}

Measure of revealed comparative advantage [12] has been used to help assess India's export potential. The RCA Index indicates whether a country has export competitiveness in a particular product that it has to offer to the World market. It helps in identifying products in which there is a trade potential. Countries with similar RCA profiles are unlikely to have high bilateral trade intensities unless intra-industry trade is involved. It is important to estimate RCA index at a disaggregate level, as it will help in focusing on the other nontraditional products that might be successfully exported.

RCA Index $>/<1$ shows commodities with comparative advantage or comparative disadvantage in the export basket of a country (World Bank, 2020). The index is given as

$$
\mathbf{R C A}_{\mathrm{ij}}=\left(\mathbf{X}_{\mathrm{ij}} / \mathbf{X i t}\right) /\left(\mathbf{X}_{\mathbf{w j}} / \mathbf{X w t}\right)
$$

Where Xij and Xwj are the values of country i's exports of product $\mathrm{j}$ and world exports of product $\mathrm{j}$ and where Xit and Xwt refer to the country's total exports and world total exports. A value of less than unity implies that the country has a revealed comparative disadvantage in the product. Similarly, if the index exceeds unity, the country is said to have a revealed comparative advantage in the product.

\section{Bilateral revealed comparative advantage (BRCA)}

The value of the index has the same meaning as that of the RCA index. The only small difference is that both destination (UAE in this case) and competing country (world in this case). It is given as:

$$
\mathrm{BRCA}_{\mathrm{ij}}^{\mathrm{k}}=\left(\mathrm{Xij}^{\mathrm{k}} / \mathrm{Xij}\right) /\left(\mathrm{Xwj}^{\mathrm{k}} / \mathbf{X w j}\right)
$$

Where $\mathrm{Xij}^{\mathrm{k}}$ is export of commodity $\mathrm{k}$ from country $\mathrm{i}$ (say India) to its partner country $\mathrm{j}$ (say UAE), $\mathrm{Xij}$ is total exports from country $\mathrm{i}$ to country $\mathrm{j}, \mathrm{Xwj} \mathrm{j}^{\mathrm{k}}$ is total world exports of commodity $\mathrm{k}$ to country $\mathrm{j}$ (UAE) and Xwj is total world exports to country j(UAE).

\section{India-UAE bilateral trade profile}

Coming to the bilateral merchandise trade between India and UAE it can be seen that the trade balance runs in favor of India. While, tracking trade profile for the last 18 years (2001 to 2018) it is found that India's exports to UAE has grown at a compound annual growth (CAGR) of $15.32 \%$. On the other hand, India's import from UAE has grown at CAGR of $21.94 \%$ during 2001 to 2018. This shows that imports from UAE has grown at a greater rate in comparison to exports to UAE. India's exports to UAE in 2001 was at the level of US \$ 2.57 billion which increased to US \$ 8.42 billion in 2005 , reached to the peak of US $\$ 37.37$ billion in 2011 before declining to US \$ 29 billion in 2018. Coming to Imports, it was US \$ 0.92 billion in 2001 increased to US $\$ 37.80$ billion in 2012 such that India ran a trade deficit of US \$ 2.02 billion. However, from there onwards it has shown a declining trend. Import from UAE in 2018 was recorded at US \$ 26.67 billion. 
Talking in terms of importance of UAE from India's point of view, it can be seen that the share (\%) of UAE in India's exports has shown an increasing trend overall, such that it increased from $5.9 \%$ in 2001 to $8.4 \%$ in 2005 reaching maximum level of $14.4 \%$ in 2009 , then declining and stabilizing at around $12 \%$ for the next three years. It was $11.3 \%$ in 2015 before declining to $9 \%$ in 2018 . In case of imports, UAE explained around $1.8 \%$ of India's total Import demand in 2001 which increased on a continuous basis and reached $8.8 \%$ in 2010 but declined further to $5.3 \%$ in 2018. In terms of exports, a share greater than $10 \%$ clearly shows the importance of UAE in India's exports strategy. Thus, constant efforts on part of the Government are required to further deepen economic ties with UAE. This is important given the current global slowdown which is indicated in stagnant share of UAE in India's total exports.

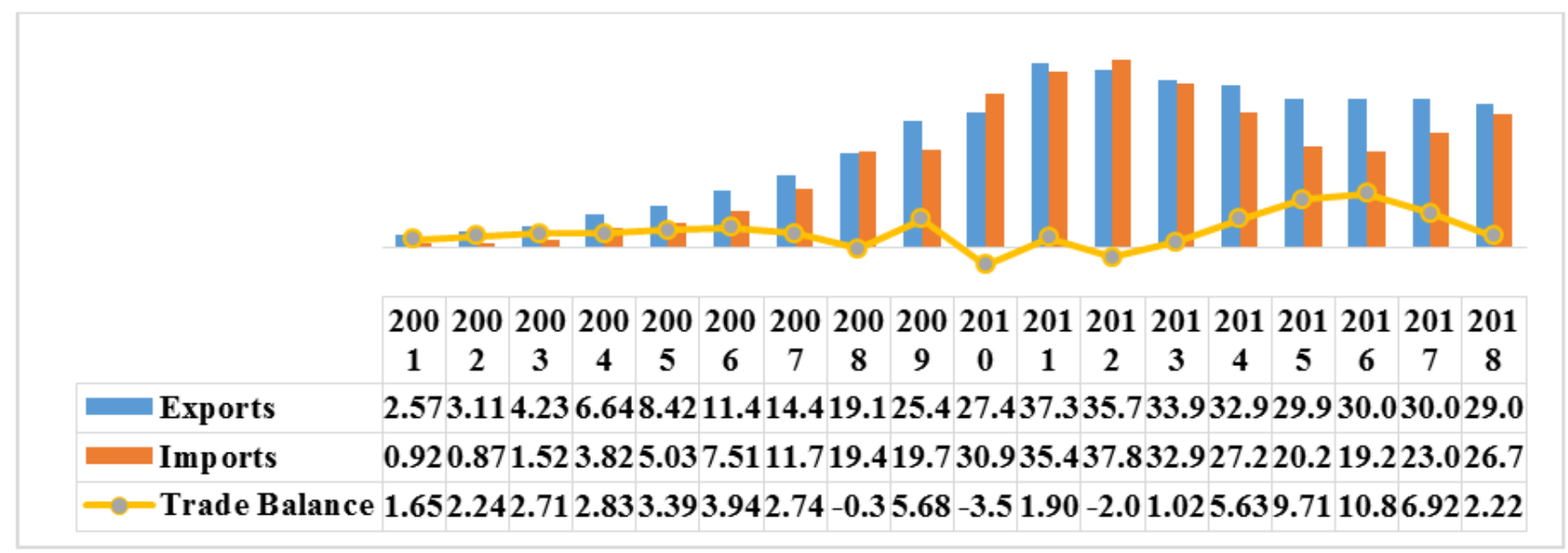

Fig-1: India's Bilateral Trade Profile with UAE, Value in US \$ Billion

Source: Authors calculation based on ITC Trade Map Database

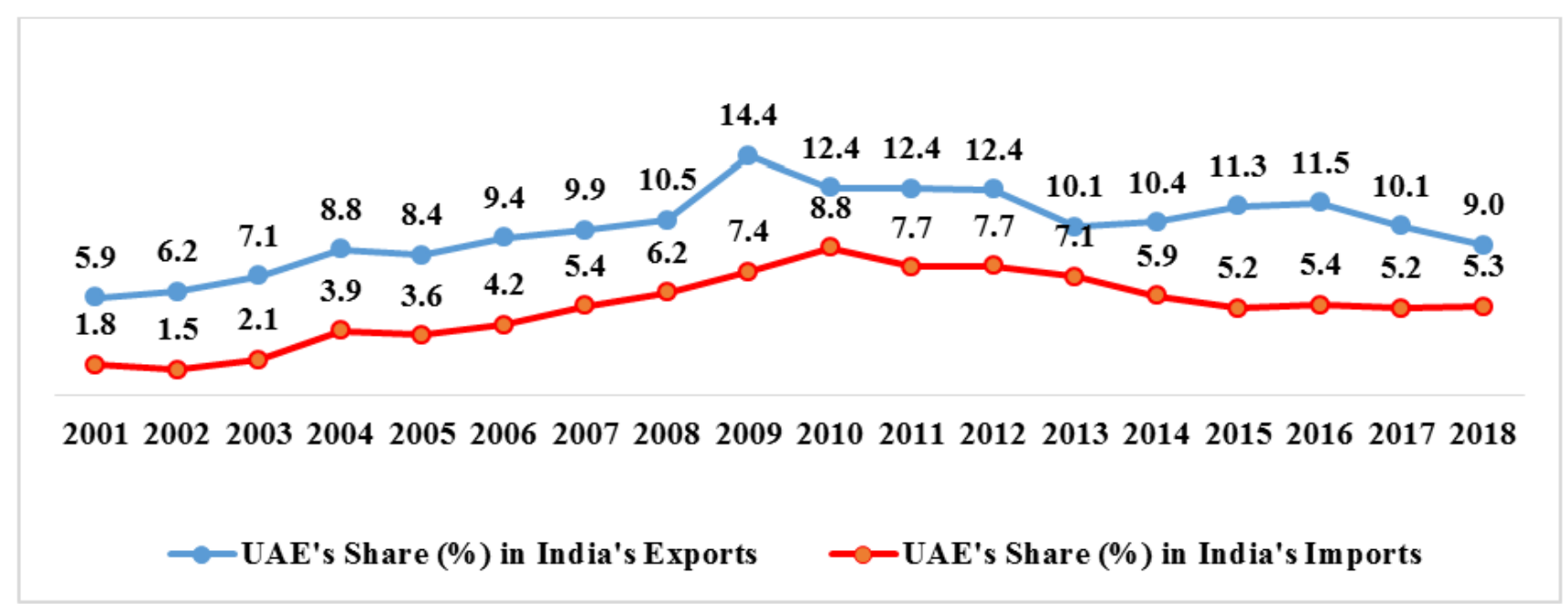

Fig-2: UAE's Share (\%) in India's Trade

Source: Authors calculation based on ITC Trade Map Database

The Table-1 below shows the historical profile of India's bilateral trade with UAE from 2001 to 2018. It shows how bilateral trade of India with UAE has changed over the years. In the year 2001 the total export value was US \$ 2569.6 million while in the year 2018 the total Export was US \$28522.8 million with the growth of around $1010 \%$. This shows that over the years UAE has become one of the most important countries for India from the point of view of trade, but at the same time Revealed Comparative Advantage suggests India has lost its competitiveness with UAE. The number of product categories which now possess comparative advantage has declined in comparison to 2001 as shown in table below. Despite recording the huge growth rate in export to UAE, India's RCA became concentrated to few categories over the year. As we can see clearly, in the year 2001 there were 8 product categories in which India had RCA but it got trimmed down to 4 product categories in the year 2018 . 
Table-1: Overview of India's Bilateral Trade with UAE (Value in US \$ Million)

\begin{tabular}{|l|l|l|l|l|l|l|l|l|}
\hline \multirow{2}{*}{$\begin{array}{l}\text { Product } \\
\text { Code }\end{array}$} & \multirow{2}{*}{ Product Description } & \multicolumn{2}{l}{ Trade Value } & \multicolumn{2}{l}{ Share in Total } & \multicolumn{2}{l}{ RCA } & \multicolumn{2}{l|}{$\begin{array}{l}\text { Compound Annual } \\
\text { Growth Rate }(\boldsymbol{\%})\end{array}$} \\
\cline { 3 - 10 } & & $\mathbf{2 0 0 1}$ & $\mathbf{2 0 1 8}$ & $\mathbf{2 0 0 1}$ & $\mathbf{2 0 1 8}$ & $\mathbf{2 0 0 1}$ & $\mathbf{2 0 1 8}$ & \\
\hline $01-05$ & Animal & 104.6 & 424.3 & 4.1 & 1.5 & 1.8 & 0.8 & 8.6 \\
\hline $06-15$ & Vegetable & 204.7 & 1185.9 & 8 & 4.2 & 2.3 & 1.5 & 10.9 \\
\hline $16-24$ & Food Products & 59.6 & 416.7 & 2.3 & 1.5 & 0.8 & 0.5 & 12.1 \\
\hline $25-26$ & Minerals & 30.3 & 64 & 1.2 & 0.2 & 2.8 & 0.5 & 4.5 \\
\hline 27 & Fuels & 3.5 & 6705.4 & 0.1 & 23.5 & 0 & 3.3 & 56.1 \\
\hline $28-38$ & Chemicals & 187.4 & 1364.8 & 7.3 & 4.8 & 1.4 & 0.9 & 12.4 \\
\hline $39-40$ & Plastic Rubber & 91.1 & 477.2 & 3.6 & 1.7 & 1.1 & 0.5 & 10.2 \\
\hline $41-43$ & Hides Skin & 9.1 & 90 & 0.4 & 0.3 & 0.7 & 0.6 & 14.5 \\
\hline $44-49$ & Wood & 21.4 & 242.5 & 0.8 & 0.9 & 0.5 & 0.5 & 15.3 \\
\hline $50-63$ & Textile \& Clothing & 712.3 & 2464.7 & 27.7 & 8.6 & 2.9 & 1.9 & 7.6 \\
\hline $64-67$ & Footwear & 11.7 & 122.3 & 0.5 & 0.4 & 0.6 & 0.6 & 14.8 \\
\hline $68-71$ & Stone \& Glass & 593.2 & 9607.1 & 23.1 & 33.7 & 2.5 & 1.8 & 17.8 \\
\hline $72-83$ & Metals & 260.2 & 1415.4 & 10.1 & 5 & 1.6 & 0.8 & 10.5 \\
\hline $84-85$ & Mach. \& Electrical & 130.2 & 2000 & 5.1 & 7 & 0.2 & 0.3 & 17.4 \\
\hline $86-89$ & Transport & 29.2 & 1712.9 & 1.1 & 6 & 0.1 & 0.4 & 27.1 \\
\hline $90-99$ & Miscellaneous & 121.1 & 229.6 & 4.7 & 0.8 & 0.6 & 0.1 & 3.8 \\
\hline $01-99$ & All & 2569.6 & 28522.8 & & & & & \\
\hline
\end{tabular}

Source: Authors Calculation based on WITS Trade Indicators

Note. Shaded Figures depict RCA

\section{RESULTS AND DISCUSSION \\ Trade Intensity Index}

Table- 2 provides calculated values of trade intensity index for different categories. In fact, from 2001 to 2018 TII is found to be more than 100 for all product categories with only one exception (fuel in
2001). Hence, it is clear that the value of overall Trade Intensity Index has shown a healthy trend during 2001 to 2018. However, TII index alone does not reflect the detailed pictures due to its focus on chapter wise results. There is a need to work on disaggregated data by using six-digit categorization.

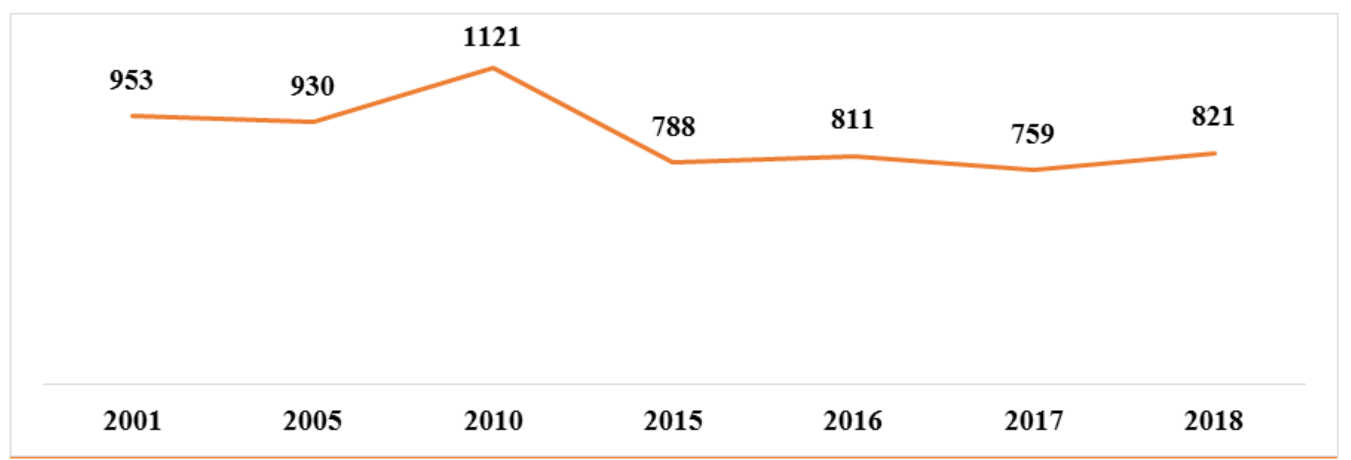

Fig-3: Trade Intensity Index (India w.r.t. UAE)

Source: WITS Trade Indicators 
Table-2: India's Category Wise Trade Intensity Index with UAE

\begin{tabular}{|l|l|l|l|l|l|l|l|}
\hline Category & $\mathbf{2 0 0 1}$ & $\mathbf{2 0 0 5}$ & $\mathbf{2 0 1 0}$ & $\mathbf{2 0 1 5}$ & $\mathbf{2 0 1 6}$ & $\mathbf{2 0 1 7}$ & $\mathbf{2 0 1 8}$ \\
\hline Total Trade & 953 & 930 & 1121 & 788 & 811 & 759 & 821 \\
\hline 01-05_Animal & 932 & 772 & 426 & 320 & 371 & 309 & 386 \\
\hline 06-15_Vegetable & 718 & 664 & 854 & 626 & 737 & 590 & 678 \\
\hline 16-24_FoodProd & 724 & 633 & 483 & 549 & 569 & 593 & 655 \\
\hline 25-26_Minerals & 812 & 337 & 560 & 423 & 518 & 248 & 408 \\
\hline 27-27_Fuels & 74 & 3056 & 2187 & 2041 & 1205 & 1384 & 2165 \\
\hline 28-38_Chemicals & 1107 & 597 & 510 & 335 & 318 & 388 & 473 \\
\hline 39-40_PlastiRub & 1567 & 1132 & 654 & 543 & 594 & 613 & 572 \\
\hline 41-43_HidesSkin & 182 & 229 & 225 & 299 & 309 & 319 & 263 \\
\hline 44-49_Wood & 2428 & 1868 & 1254 & 972 & 1033 & 1163 & 1207 \\
\hline 50-63_TextCloth & 657 & 490 & 447 & 542 & 617 & 663 & 531 \\
\hline 64-67_Footwear & 313 & 257 & 249 & 369 & 321 & 321 & 381 \\
\hline 68-71_StoneGlas & 412 & 481 & 801 & 620 & 567 & 442 & 481 \\
\hline 72-83_Metals & 1444 & 975 & 671 & 598 & 611 & 579 & 514 \\
\hline 84-85_MachElec & 720 & 677 & 626 & 474 & 525 & 453 & 664 \\
\hline 86-89_Transport & 453 & 530 & 271 & 479 & 406 & 498 & 518 \\
\hline 90-99_Miscellan & 1214 & 765 & 755 & 257 & 401 & 409 & 437 \\
\hline
\end{tabular}

Source: WITS Trade Indicators

Note: Shaded box represents categories and years with high Trade Intensity

\section{The trade complementarity index}

In the Figure-4 given below it can be seen that, from 2001 to 2018 , the trade complementary index varies from 55.9 to 61.93 , this implies that the complementarity of India-UAE trade remained partially matched. The higher the value of the index toward 100 the higher the sufficiency of India's exports supply in meeting UAE import demand. The result from trade complementarity index shows that India can only come across slice of what UAE requires, from its available export supply. In 2001, the TCI is 55.9 implying that India was only capable of meeting 55.9 percent of UAE import demand. In 2015 , the TCI had dip to 52.25 implying that in comparison to 2001 index of 55.9, India's export supply was relatively low to UAE import demand. In the year 2018, the TCI rose to 61.93, implying that in comparison to 2015 index of 52.25, India's export supply was becoming more compatible to UAE import demand.

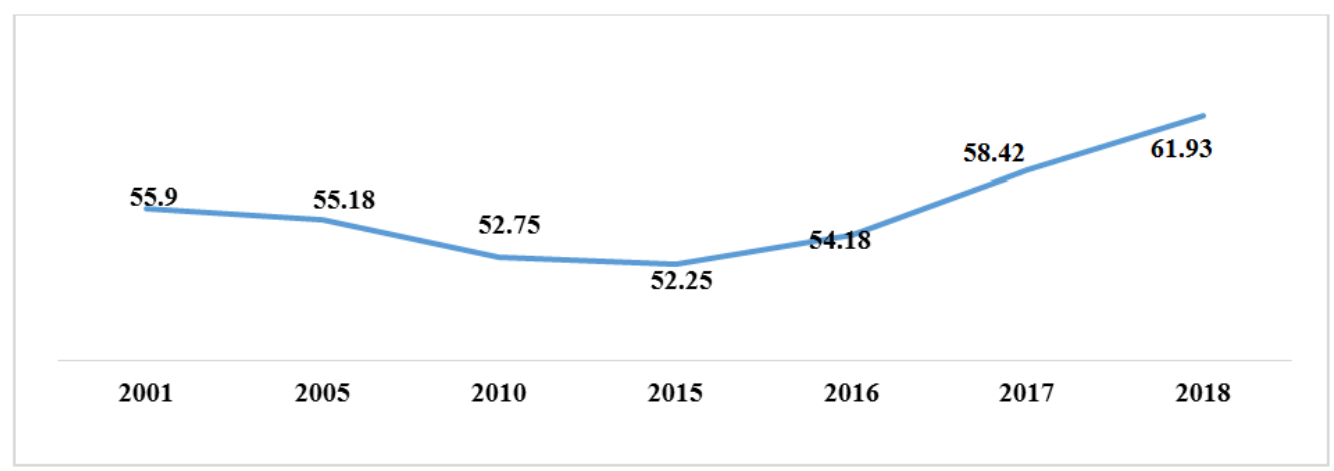

Fig-4: Trade Complementary Index (India w.r.t UAE)

Source: WITS Trade Indicators

This compatibility also indicates changes in India's trade profile towards a more diversified economy. However, if we relate TCI to TTI there is some contradiction. TTI shows healthy trade intensity while TCI suggests there is a potential gap from India's point of view. One possible reason could be less diversified export basket. For understanding export diversification, it is also important to use Hirschman Herfindahl Product Concentration Index.

\section{Hirschman Herfindahl index}

Figure-5 below represents the diverseness of India's export products to the UAE import basket using
Hirschman Herfindhal Index (HHI). In the year 2001 the HHI was 0.0285 which increased to 0.1422 in 2010 again declining to 0.0683 in 2015 . This shows that India's HHI product concentration Index varied considerably over the years. The value of HHI Index increased to 0.1251 in 2018 showing more concentrated basket India has to offer UAE. The average HHI Index over these seven years mentioned below comes out to be 0.0815 . Thus, it can be seen that Index value indicates a low diversified product basket. All this suggest that India has not diversified much over the time. 


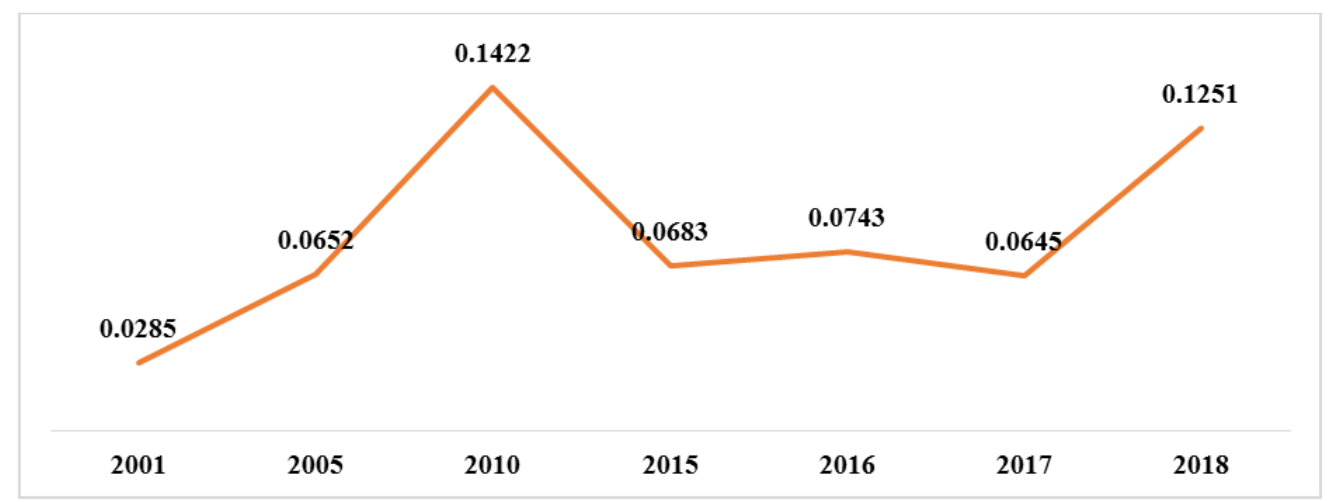

Fig-5: HHI Product Index (India w.r.t UAE)

Source: WITS Trade Indicators

\section{India's RCA with the World \& BRCA with United Arab Emirates}

For the present analysis, India's competitiveness is analyzed both at the Global level i.e., RCA [12] with world and at Bilateral level with UAE i.e. BRCA with UAE in competition with World. The main objective here is to identify products or tariff lines at which India is having comparative advantage globally and is competitive in UAE. The reason for computing RCA and BRCA is that it is quite possible that in certain tariff line India might be competitive globally but may not be competitive in UAE. Thus, at the end we can come up with list of products that can be proposed or extended to UAE given the fact that UAE may be a great buyer of those products but may not be buying it from India [ $\left.{ }^{1}\right]$.

Table-3 given below explains the distribution of HS 6-digit lines in which India has RCA across chapters (the list is sorted based on export values of products India having RCA in the World in 2018 at HS6 digit falling under each chapter). The top 25 products in terms of export values explain around $33.6 \%$ of India's total export earnings in 2018.

After analyzing the product in terms of their distributional impact across chapters it can be seen that there are total 63 in chapter 63 where India has RCA and these 63 explain around $37.8 \%$ of India's total exports revenue under this chapter to world in 2018. Similarly, there are 48 products which fall in Chapter

\footnotetext{
${ }^{1}$ The main approach of this study is to focus on only those tariff lines at which India have RCA and BRCA for the years taken into consideration (2001, 2005, 2010, 2015, $2017 \& 2018$ ). The main reason being is that it is quite possible that India might be having RCA and BRCA in a particular year but may not enjoy competitiveness in the following years. Thus, in order to come up with a concrete list that can be proposed further to increase trade with a particular country it is important that we should investigate only those products that have competitiveness in all the years which are taken into consideration.
}

52 (cotton) which explains $52.3 \%$ of export revenue in the year 2018. If we give a quick look at the table given below it can be seen that most of the products that enjoy RCA fall under Organic chemical, textiles, Iron \& steel. However, one point which requires further deliberation is identification of part of the value chain these lines fall. India is still in lower part of the value which will act an impediment for securing high export growth in the long run.

Some of the products in which India has RCA are; HS-291431 (Phenyl acetone "phenylpropan- 2one"), HS-294200 (Separate chemically defined organic compounds, n.e.s.), HS- 290611(Menthol), HS-292221 (Amino hydroxyl naphthalene sulphonic acids and their salts), HS-293942 (Pseudoephedrine "INN" and its salts), HS - 293941 (Ephedrine and its salts), HS292142 (Aniline derivatives and their salts), HS 292243 (Anthracitic acid and its salts), HS- 294150 (Erythromycin and its derivatives; salts thereof) etc. Under the cotton products category the tariff line enjoying RCA are HS-520535 (Multiple "folded" or cabled cotton yarn, of uncombed fibers, containing $>=$ $85 \%$ cotton by weight ...), HS-520533 (Multiple "folded" or cabled cotton yarn, of uncombed fibers, containing $>=85 \%$ cotton by weight ...), HS -520523 (Single cotton yarn, of combed fibers, containing >= $85 \%$ cotton by weight and with a linear ...), HS-520547 (Multiple "folded" or cabled cotton yarn, of combed fibers, containing $>=85 \%$ cotton by weight ... ), HS520524 (Single cotton yarn, of combed fibers, containing $>=85 \%$ cotton by weight and with a linear ...), HS - 520527 (Single cotton yarn, of combed fibers, containing $>=85 \%$ cotton by weight and with a linear ...) etc. The products under chapter 62 i.e. Articles of apparel and clothing accessories are HS-621142 (Women or girls' tracksuits and other garments, n.e.s. of cotton (excluding knitted or crocheted)), HS-620419 (Women or girls' suits of textile materials (excluding of wool, fine animal hair, cotton or ...) etc.

The other major chapter where India has RCA is chapter 71 (Gems \& Jewellery sectors). Chapter 71, though has only few tariff lines, explains major proportion of India's exports earnings. Specific 
products from this chapter are; HS-710239 (Diamonds, worked, but not mounted or set excluding industrial diamonds), HS-711319 (Articles of jewellery and parts thereof, of precious metal other than silver, whether or not ...), HS-711311 (Articles of jewellery and parts thereof, of silver, whether or not plated or clad with other ...), HS-711790 (Imitation jewellery excluding jewellery, of base metal, whether or not clad with silver, gold...), HS-710391 (Rubies, sapphires and emeralds, worked, whether or not graded, but not strung, mounted or set, ...), etc. The six products having RCA under chapter 71 explains around $92 \%$ of total exports earning in 2018 from chapter 71. Commodities from chapter 61 (Articles of apparel and clothing accessories) having RCA explains around 64\% of Exports earnings from this chapters. There are 23 products from chapter 61 at HS 6-digit lines in which India has RCA. The other major category having products, which have RCA at HS 6-digit levels is Chapter 57 (carpets), where 13 products have RCA together explaining around $82 \%$ of total exports earning in this chapter. Besides, products from chemicals, textiles, and Gems \& Jewellery sectors, there are products from Engineering sectors also. This includes products from chapter 73 (Articles of Iron \& steel); total of 17 products having RCA at HS 6-digit level explaining around $46 \%$ of total exports revenue. Chapter 72 (iron \& steel) have total of 15 products having RCA explaining around $41 \%$ of export values in 2018. Chapter 87 (Vehicles other than railways or tramways) have 5 products having RCA showing $21 \%$ of export earnings.

In conclusion we can say that products in which India have RCA are mainly from Organic Chemical, Textiles, Gems \& Jewellery, Engineering Sector, Pharmaceutical products, Electrical machinery, Plastics and articles thereof, Salt Sulphur etc. However, it is important to note that besides textiles, Organic Chemicals, Inorganic Chemicals, there are only few products from other chapters. It is found that India's competitiveness is limited to only few tariff lines at HS 6-digit level.

Table-3: Distribution of Products India's having RCA Globally and its Share in respective Chapters at HS-2-digit Level and in India's Total Exports, Value in US \$ billion, Year 2018

\begin{tabular}{|c|c|c|c|c|c|c|c|}
\hline $\begin{array}{l}\mathbf{S} . \\
\mathbf{N} \\
\mathbf{0}\end{array}$ & $\begin{array}{l}\text { HS- } \\
\text { 2di } \\
\text { git }\end{array}$ & Description & $\begin{array}{l}\text { Total } \\
\text { Export } \\
\#\end{array}$ & $\begin{array}{l}\text { Number of } \\
\text { Products } \\
\text { India having } \\
\text { RCA \#\# }\end{array}$ & $\begin{array}{l}\text { Export Value } \\
\text { of Products } \\
\text { India having } \\
\text { RCA \#\#\# }\end{array}$ & $\begin{array}{l}\text { \% Share } \\
\text { of } \\
\text { Exports } \\
\text { under } \\
\text { HS-2- } \\
\text { digit\#\#\# }\end{array}$ & $\begin{array}{l}\text { \% Share of } \\
\text { Exports in } \\
\text { India's total } \\
\text { Exports\#\#\#\# } \\
\#\end{array}$ \\
\hline 1 & 71 & $\begin{array}{l}\text { Natural or cultured pearls, precious or } \\
\text { semi-precious stones, precious metals, } \\
\text { metals clad ... }\end{array}$ & 40.1 & 6 & 37.2 & 92.7 & 11.5 \\
\hline 2 & 10 & Cereals & 7.8 & 1 & 6.9 & 88.5 & 2.1 \\
\hline 3 & 29 & Organic chemicals & 17.7 & 63 & 6.7 & 37.8 & 2.1 \\
\hline 4 & 62 & $\begin{array}{l}\text { Articles of apparel and clothing } \\
\text { accessories, not knitted or crocheted }\end{array}$ & 8.1 & 44 & 6.3 & 77.8 & 2 \\
\hline 5 & 61 & $\begin{array}{l}\text { Articles of apparel and clothing } \\
\text { accessories, knitted or crocheted }\end{array}$ & 7.6 & 23 & 4.9 & 64.2 & 1.5 \\
\hline 6 & 52 & Cotton & 8.1 & 48 & 4.3 & 52.3 & 1.3 \\
\hline 7 & 72 & Iron and steel & 10 & 15 & 4.1 & 41.4 & 1.3 \\
\hline 8 & 87 & $\begin{array}{l}\text { Vehicles other than railway or tramway } \\
\text { rolling stock, and parts and accessories } \\
\text { thereof }\end{array}$ & 18.2 & 5 & 4 & 21.8 & 1.2 \\
\hline 9 & 63 & $\begin{array}{l}\text { Other made-up textile articles; sets; worn } \\
\text { clothing and worn textile articles; rags }\end{array}$ & 5.2 & 18 & 3.8 & 72.8 & 1.2 \\
\hline 10 & 2 & Meat and edible meat offal & 3.7 & 2 & 3.4 & 91.9 & 1.1 \\
\hline 11 & 76 & Aluminium and articles thereof & 5.1 & 5 & 3.4 & 65.6 & 1 \\
\hline 12 & 73 & Articles of iron or steel & 7.1 & 17 & 3.3 & 46.1 & 1 \\
\hline 13 & 32 & $\begin{array}{l}\text { Tanning or dyeing extracts; tannins and } \\
\text { their derivatives; dyes, pigments and } \\
\text { other colouring ... }\end{array}$ & 3.2 & 14 & 2.6 & 79.8 & 0.8 \\
\hline 14 & 30 & Pharmaceutical products & 14.3 & 4 & 2.1 & 14.4 & 0.6 \\
\hline 15 & 42 & $\begin{array}{l}\text { Articles of leather; saddlery and harness; } \\
\text { travel goods, handbags and similar } \\
\text { containers; articles ... }\end{array}$ & 2.5 & 9 & 2 & 80.4 & 0.6 \\
\hline 16 & 39 & Plastics and articles thereof & 7.8 & 5 & 1.7 & 22.1 & 0.5 \\
\hline 17 & 9 & Coffee, tea, maté and spices & 3.1 & 8 & 1.7 & 55.4 & 0.5 \\
\hline 18 & 25 & $\begin{array}{l}\text { Salt; sulphur; earths and stone; plastering } \\
\text { materials, lime and cement }\end{array}$ & 2.3 & 17 & 1.7 & 74.1 & 0.5 \\
\hline 19 & 64 & $\begin{array}{l}\text { Footwear, gaiters and the like; parts of } \\
\text { such articles }\end{array}$ & 2.8 & 4 & 1.6 & 57.9 & 0.5 \\
\hline
\end{tabular}




\begin{tabular}{|l|l|l|l|l|l|l|l|}
\hline 20 & 85 & $\begin{array}{l}\text { Electrical machinery and equipment and } \\
\text { parts thereof; sound recorders and } \\
\text { reproducers, television ... }\end{array}$ & 11.8 & 11 & 1.6 & 13.5 & 0.5 \\
\hline 21 & 57 & Carpets and other textile floor coverings & 1.7 & 13 & 1.4 & 82.5 & 0.4 \\
\hline 22 & 55 & Man-made staple fibres & 1.9 & 21 & 1.4 & 75.1 & 0.4 \\
\hline 23 & 54 & $\begin{array}{l}\text { Man-made filaments; strip and the like of } \\
\text { man-made textile materials }\end{array}$ & 2.3 & 14 & 1.4 & 60.9 & 0.4 \\
\hline 24 & 13 & $\begin{array}{l}\text { Lac; gums, resins and other vegetable } \\
\text { saps and extracts }\end{array}$ & 1.1 & 4 & 1.1 & 99.5 & 0.3 \\
\hline 25 & 23 & $\begin{array}{l}\text { Residues and waste from the food } \\
\text { industries; prepared animal fodder }\end{array}$ & 1.7 & 4 & 1 & 62.3 & 0.3 \\
\hline & Sum of Top 25 Exports to World & 195.2 & 375 & 109.6 & & 33.6 \\
\hline
\end{tabular}

Source: Calculation based on ITC Trade Map and WITS database Notes:

1. *India's Total Exports in 2018 was US \$ 323.05 billion

2. \# It shows Total Exports Value under each chapter i.e. at HS-2-digit level

3. \# \# It shows number of products India having RCA at Hs-6-digit and falling under each chapter. Basically, distribution of Competitive products across each chapter i.e. at HS-2-digit.

4. \#\#\# Export value of Products having RCA at HS 6 digit

5. \#\#\#\# \% Share of Export earning explained by Products having RCA in each chapter

6. \#\#\#\#\# \% Share Export earning explained by Products having RCA in India's Total Exports in FY 2018-19 (i.e. out of US \$ 323 billion what percentage of Revenue is explained by Competitive Products)

BRCA Analysis: Bilateral RCA analysis suggests major categories where India enjoys comparative advantage in UAE over the World are; Products from Gems \& Jewellery, Textiles sector, Iron \& Steel, Organic Chemicals, Coffee and Edibles fruits and nuts, Tobacco and manufactured tobacco substitutes. The major exported commodity to UAE where India enjoys significant advantage is of natural or cultured pearls, precious or semi-precious stone precious metals, metals clad etc. as this category explains around $30 \%$ of total export revenue from UAE and $88.9 \%$ of earnings within the chapters. This includes products such as HS-711319 (Articles of jewellery and parts thereof, of precious metal other than silver, whether or not ...) \& HS- 710239 (Diamonds, worked, but not mounted or set excluding industrial diamonds). The other major category is chapter 62 (Articles of apparel and clothing accessories, not knitted or crocheted), including following products; HS620520 (Men's or boys' shirts of cotton (excluding knitted or crocheted, nightshirts, singlets and ...), HS621490 (Shawls, scarves, mufflers, mantillas, veils and similar articles of textile materials (excluding ...), HS620590 (Men's or boys' shirts of textile materials (excluding of cotton or man-made fibres, knitted ...), HS-620349 (Men's or boys' trousers, bib and brace overalls, breeches and shorts of textile materials excluding ...), HS-620443 (Women's or girls' dresses of synthetic fibres (excluding knitted or crocheted and petticoats), HS-620930 (Babies' garments and clothing accessories of synthetic fibers (excluding knitted or crocheted ...), HS-621410 (Shawls, scarves, mufflers, mantillas, veils and similar articles of silk or silk waste (excluding ...) etc. There are 28 chapters explaining around $1.8 \%$ of Total Export earnings from UAE and $66.4 \%$ of export earnings from Chapter 62. From chapter 10 (cereals) there is only one product in which India have BRCA in UAE, this is HS-100630 (Semimilled or wholly milled rice, whether or not polished or glazed) explain $1.8 \%$ of Export revenue from UAE and $97 \%$ of earning within that chapter exported to UAE. The other major products in which India has BRCA belongs to chapters 61 (Articles of apparel and clothing accessories, knitted or crocheted), Chapter 72 (Iron \& Steel), Chapter 73 (Articles of Iron \& Steel), Chapter 8 (Edible fruit and nuts; peel of citrus fruit or melons), chapter 63 (Other made-up textile articles; sets; worn clothing and worn textile articles; rags), chapters 24 (Tobacco and manufactured tobacco substitutes). One thing, quite evident from Table 4 is that India's competitiveness is very much concentrated in few lines or sectors. It is found that products having BRCA from top 10 categories explains around $40 \%$ of India's total exports earning from UAE and even in that $40 \%, 30 \%$ of earnings comes from chapter 71 . 
Table-4: Distribution of Products India's having BRCA in UAE at HS 6 digit and its Share in respective Chapters at HS- 2-digit Level and in total Exports to UAE, Value in US \$ Billion, Year 2018

\begin{tabular}{|c|c|c|c|c|c|c|c|}
\hline $\begin{array}{l}\text { S. } \\
\text { No }\end{array}$ & $\begin{array}{l}\text { HS_2 } \\
\text { Digit }\end{array}$ & Description & $\begin{array}{l}\text { Total } \\
\text { Expor } \\
\text { ts to } \\
\text { UAE\# }\end{array}$ & $\begin{array}{l}\text { Number of } \\
\text { Products } \\
\text { India } \\
\text { having } \\
\text { BRCA \#\# }\end{array}$ & $\begin{array}{l}\text { Export Value } \\
\text { of Products } \\
\text { India having } \\
\text { BRCA \#\#\# }\end{array}$ & $\begin{array}{l}\text { \% Share } \\
\text { of Exports } \\
\text { under HS- } \\
\text { 2-digit\#\#\#\# }\end{array}$ & $\begin{array}{l}\text { \% Share of } \\
\text { Exports in } \\
\text { India's total } \\
\text { Exports to } \\
\text { UAE\#\#\#\#\# }\end{array}$ \\
\hline 1 & 71 & $\begin{array}{l}\text { Natural or cultured pearls, precious or } \\
\text { semi-precious stones, precious metals, } \\
\text { metals clad ... }\end{array}$ & 9.8 & 3 & 8.7 & 88.9 & 30.0 \\
\hline 2 & 62 & $\begin{array}{l}\text { Articles of apparel and clothing } \\
\text { accessories, not knitted or crocheted }\end{array}$ & 0.8 & 28 & 0.5 & 66.4 & 1.8 \\
\hline 3 & 10 & Cereals & 0.5 & 1 & 0.5 & 97.9 & 1.8 \\
\hline 4 & 61 & $\begin{array}{l}\text { Articles of apparel and clothing } \\
\text { accessories, knitted or crocheted }\end{array}$ & 1.1 & 16 & 0.5 & 41.7 & 1.6 \\
\hline 5 & 72 & Iron and steel & 0.7 & 11 & 0.2 & 35.4 & 0.8 \\
\hline 6 & 8 & $\begin{array}{l}\text { Edible fruit and nuts; peel of citrus fruit or } \\
\text { melons }\end{array}$ & 0.3 & 5 & 0.2 & 71.9 & 0.7 \\
\hline 7 & 73 & Articles of iron or steel & 0.4 & 8 & 0.1 & 25.6 & 0.4 \\
\hline 8 & 63 & $\begin{array}{l}\text { Other made-up textile articles; sets; worn } \\
\text { clothing and worn textile articles; rags }\end{array}$ & 0.2 & 7 & 0.1 & 59.8 & 0.3 \\
\hline 9 & 24 & $\begin{array}{l}\text { Tobacco and manufactured tobacco } \\
\text { substitutes }\end{array}$ & 0.1 & 1 & 0.1 & 71.7 & 0.3 \\
\hline 10 & 2 & Meat and edible meat offal & 0.2 & 1 & 0.1 & 50.0 & 0.3 \\
\hline 11 & 9 & Coffee, tea, maté and spices & 0.2 & 6 & 0.1 & 55.9 & 0.3 \\
\hline 12 & 22 & Beverages, spirits and vinegar & 0.1 & 1 & 0.1 & 69.1 & 0.2 \\
\hline 13 & 7 & $\begin{array}{l}\text { Edible vegetables and certain roots and } \\
\text { tubers }\end{array}$ & 0.1 & 2 & 0.1 & 37.6 & 0.2 \\
\hline 14 & 29 & Organic chemicals & 0.5 & 13 & 0.1 & 11.4 & 0.2 \\
\hline 15 & 82 & $\begin{array}{l}\text { Tools, implements, cutlery, spoons and } \\
\text { forks, of base metal; parts thereof of base } \\
\text { metal }\end{array}$ & 0.1 & 5 & 0.0 & 72.3 & 0.2 \\
\hline 16 & 68 & $\begin{array}{l}\text { Articles of stone, plaster, cement, asbestos, } \\
\text { mica or similar materials }\end{array}$ & 0.1 & 1 & 0.0 & 47.9 & 0.2 \\
\hline 17 & 52 & Cotton & 0.1 & 14 & 0.0 & 68.0 & 0.1 \\
\hline 18 & 42 & $\begin{array}{l}\text { Articles of leather; saddlery and harness; } \\
\text { travel goods, handbags and similar } \\
\text { containers; articles ... }\end{array}$ & 0.1 & 3 & 0.0 & 42.5 & 0.1 \\
\hline 19 & 74 & Copper and articles thereof & 0.1 & 3 & 0.0 & 63.8 & 0.1 \\
\hline 20 & 48 & $\begin{array}{l}\text { Paper and paperboard; articles of paper } \\
\text { pulp, of paper or of paperboard }\end{array}$ & 0.2 & 3 & 0.0 & 16.8 & 0.1 \\
\hline 21 & 55 & Man-made staple fibres & 0.1 & 8 & 0.0 & 63.3 & 0.1 \\
\hline 22 & 54 & $\begin{array}{l}\text { Man-made filaments; strip and the like of } \\
\text { man-made textile materials }\end{array}$ & 0.1 & 8 & 0.0 & 25.9 & 0.1 \\
\hline 23 & 85 & $\begin{array}{l}\text { Electrical machinery and equipment and } \\
\text { parts thereof; sound recorders and } \\
\text { reproducers, television ... }\end{array}$ & 1.3 & 4 & 0.0 & 1.5 & 0.1 \\
\hline 24 & 4 & $\begin{array}{l}\text { Dairy produce; birds' eggs; natural honey; } \\
\text { edible products of animal origin, not } \\
\text { elsewhere ... }\end{array}$ & 0.0 & 1 & 0.0 & 40.4 & 0.1 \\
\hline \multirow[t]{3}{*}{25} & 39 & Plastics and articles thereof & 0.4 & 3 & 0.0 & 5.0 & 0.1 \\
\hline & & $\begin{array}{l}\text { Sum of Top } 25 \text { Exports to UAE Having } \\
\text { BRCA }\end{array}$ & 17.5 & 156 & 11.7 & & 40.3 \\
\hline & & Total & 26.4 & 228 & 11.9 & & 40.9 \\
\hline
\end{tabular}

Source: Calculation based on ITC Trade Map and WITS database Notes:

1. *India's Total Exports to UAE in 2018 was US \$ 29.003 billion

2. \# It shows Total Exports Value to UAE under each chapter i.e. at HS-2-digit level

3. \# \# It shows number of products India having BRCA at Hs-6-digit and falling under each chapters. Basically, distribution of Competitive products across each chapter i.e. at HS-2-digit.

4. \#\#\# Export value of Products having BRCA at HS 6 digit

5. \#\#\#\# \% Share of Export earning explained by Products having BRCA in each chapter

6. \#\#\#\#\# \% Share Export earning explained by Products having BRCA in India's Total Exports to UAE in FY 2018-19 (i.e. out of US $\$ 29.003$ billion what percentage of Revenue is explained by Competitive Products) 
Some of the products which explains around $50 \%$ of 6.42 billion of UAE demands are HS- 271312 (Petroleum coke, calcined), HS-420221 (Handbags, whether or not with shoulder straps, incl. those without handles, with outer surface ...), HS-240120 (Tobacco, partly or wholly stemmed or stripped, otherwise unmanufactured), HS-401120 (New pneumatic types, of rubber, of a kind used for buses and lorries, excluding types with ...), HS-300420 (Medicaments containing antibiotics, put up in measured doses "incl. those in the form of transdermal ...), HS-390210 (Polypropylene, in primary forms), HS-711311 (Articles of jewellery and parts thereof, of silver, whether or not plated or clad with other ...), HS-680221 (Marble, travertine and alabaster articles thereof, simply cut or sawn, with a flat or even ...), HS -710391 (Rubies, sapphires and emeralds, worked, whether or not graded, but not strung, mounted or set, ...), HS850423 (Liquid dielectric transformers, having a power handling capacity > $10.000 \mathrm{kVA}$ ), HS-20421 (Fresh or chilled sheep carcases and half-carcases (excluding lambs), HS-610342 (Men's or boys' trousers, bib and brace overalls, breeches and shorts of cotton, knitted or ...), HS-854511 (Electrodes of graphite or other carbon, for electric furnaces), HS-730791 (Flanges of iron or steel (excluding cast or stainless products), HS- 620449 (Women's or girls' dresses of textile materials (excluding of wool, fine animal hair, cotton) HS620640 (Women's or girls' blouses, shirts and shirtblouses of man-made fibres, excluding knitted or ...), HS-710399 (Precious and semi-precious stones, worked, whether or not graded, but not strung, mounted).

Our analysis suggests that India has RCA globally in 558 products while BRCA with UAE is limited only for 228 products. Thus, there are 377 products in which India does not have BRCA in UAE but have RCA globally. In 2018, UAE's Import of these 377 products stood at US\$

6.42 billion out of US\$ 261.51 billion of UAE's total Imports. These 377 products explain around $2.45 \%$ of UAE's total imports in 2018. India's export to the rest of the World of these products in 2018 was recorded at around US\$ 44.11 billion. Thus, India definitely has room and potential to capture some share of US\$ 6.42 billion imported by UAE. Appropriate policy measures are required to find out the exact reason why India is not able to capture a major proportion of UAE's import as India's exports to UAE for these 377 products were only US\$ 1.21 billion in 2018.

\section{CONCLUSION}

The study suggests that integration between India and UAE increases considerably during last two decades. This is true despite the fact that global trade was on the lower trajectory given the aftermath of Subprime crisis in USA and subsequent economic recession. This is evident from the fact that UAE continuously features among the Top 5 trading partners of India. India has integrated itself with the world economy by bringing certain institutional changes in domestic policies, and continuously trying to improve its position in world market as a supplier. The Trade intensity between the two countries has increased over the year and is found to be high in case of chemicals, woods, textiles and clothing. Over the years, India though diversified it exports basket, is still heavily dependent on few lines for major share of the export earnings from UAE. We found that Gems \& Jewellery accounts for $30 \%$ of the total export values in 2018 and this comes from only two categories at HS 6-digit lines. This makes India's export earning very much prone to fluctuation in global financial and geopolitical turmoil. Detailed competitive analysis carried out at HS 6 digit shows that India holds competitive advantage in $9 \%$ of UAE's total import demand i.e. India has bilateral revealed competitive advantage in 288 tariff lines which accounts for 9\% of UAE's total Import (US \$ 23.59 billion/US \$ 261.51 billion) in 2018. For India there exists a window of opportunity in terms 377 products at HS 6 digit where it holds competitive advantage globally but do not possess bilateral competitive advantage with UAE in comparison to another supplier. There is an opportunity for India to tap a market of around US \$ 6.42 billion of which India supplies only US \$ 1.21 billion.

Nevertheless, the magnitude of India's exhaustive and sincere efforts to become competitive economy in the world should not be ignored. It is due to these comprehensive efforts that India was placed at number 16th in terms of total exports and at number 11 th in terms of total import in the year 2018. India is also continuously pushing itself to enlarge its horizons towards the diversification of its products in the bilateral market. Moreover, a further analysis is imperative to carve out as to where does India stands in comparison to the top suppliers to UAE viz-a viz the demand of UAE from world? This will further help to come up with few more products where India would be in a position to grab the opportunity in few more sectors such as Drugs \& Pharma, Engineering and textiles reason being its exhaustive production capacity in these sectors. As these are the sectors where India can actually further diversify itself to improve its position in terms of export and as a potential supplier to meet the import demand generated by UAE.

The second point of investigation should be in terms of market access, i.e. analyzing the tariff relaxation offered by the two countries to each other in comparison to what they offer to their other major trading partners and try seeing if there is any further possibility to work on it to further boost trade between the two countries. An added analysis on Non-Tariff Measures (NTMs) would also be desirable given the fact that over the last decade, NTMs have gathered a 
central position in trade negotiations among leading trade countries. In this particular case it would be important to focus more on Sanitary \& Phyto Sanitary Measures (SPS) and Technical Barriers to Trade (TBT) as they are the important measures nation often resort to protect their market.

\section{REFERENCES}

1. Panagariya, A. (2004, December 24). India's Trade Reform. Retrieved from brookings: www.brookings.edu

2. Commerce, D. O. (2020). Ministry of Commerce. Retrieved from https://tradestat.commerce.gov.in/ftpa/cnt.asp: https://tradestat.commerce.gov.in/ftpa/cnt.asp

3. Tesorero, A. (2017, January 21). UAE-India: A partnership that dates back centuries. Khaleej Times, 1-5.

4. Das, P., \& Pradhan, S. (2014). India-Gulf Trade Relations, IOSR Journal of Economics and Finance, 31-41.

5. Mohajeri, P. (2015). Trends of India Trade with Persian Gulf Countries, Indian Journal of Applied Research, 199-207.
6. Goyal, K., \& Vajid, A. (2018). An Analysis of India's Trade Intensity With UAE, Journal of Commerce \& Trade, 27-31.

7. Alam, I., \& Ahmed, S. (2017). Demystifying the Puzzle between India-UAE Trade: An Analytical Study, The Empirical Economics Letters, 1256-66.

8. Ahmad, I., Kunroo, M., \& Sofi, I. (2018). An RCA Analysis of India-China Trade Integration: Present Potential and Prospects, Foreign Trade Review, 1-10.

9. Nation, U. (2020, July 20). UN Trade Statistics. Retrieved from United Nation International Trade Statistics Knowledgebase: https://unstats.un.org/unsd/tradekb/Knowledgebas e/50018/Harmonized-Commodity-Descriptionand-Coding-Systems-HS

10. Nation, U. (2020, July 20). UN Comtrade Database. Retrieved from Comtrade: https://comtrade.un.org/

11. World Bank. (2020, July 26). Retrieved from WITS: https://wits.worldbank.org/

12. Balassa, B. (1965). Trade Liberalisation and 'Revealed' Comparative Advantage, The Manchester School, 99-123. 